\title{
Sporobolomyces roseus, a Causal Agent of Citrus Pseudo Greasy Spot (Nise-Ohan-Byo) and the Infection Process of Disease
}

\author{
Meisaku KoIzumi
}

\begin{abstract}
Based on the carotenoid pigmentation and the formation of kidney-shape and oval ballistospores the yeast causing pseudo greasy spot (PGS) is considered to belong to the genus Sporobolomyces. No assimilation of inositol, utilization of nitrate, absence of pseudo- or true mycelium and assimilation of soluble starch indicate that the species is Sporobolomyces roseus Kluyver et van Niel. The yeast cells multiplied on the surface of citrus leaves and some of them entered host tissues through the stomatal pores. The invading yeast cells multiplied in the intercellular spaces, but soon became immobilized and embedded with electrondense materials. The host cells adjacent to the invaded pathogens did not collapse, but their plasmalemma, tonoplast and chloroplasts degenerated.
\end{abstract}

(Received May 21, 1986)

Key words : citrus pseudo greasy spot, Sporobolomyces roseus, infection mode.

\section{Introduction}

In a previous report ${ }^{3)}$, Sporobolomyces sp. and Aureobasidium sp. were isolated from citrus leaves with pseudo greasy spot (PGS, Nise-ohan-byo), which is prevalent in southwestern Japan. Based on pathogenic activity, sensitivity to fungicides and ecological properties, a Sporobolomyces sp. is thought to be the major causal fungus. According to the yeast taxonomy system ${ }^{2}$, there are seven species in genus Sporobolomyces. These are differenciated on the basis of their ability to utilize nitrate, inositol and some other carbon sources, and to form pseudo- or true mycelium. This paper deals with the identification of the yeast that causes PGS and with some histological observations on the infection process.

\section{Materials and Methods}

Isolates used. The pathogenic isolates of ballistosporogenous yeasts No. 3, 4 and 6, which had been stored under liquid paraffin on yeast extract-malt extract (YM) agar medium and kept in a refrigerator. YM medium contains following materials per liter

Contribution No. Fruit Tree Res. Stn. : D-73

Okitsu Branch, Fruit Tree Research Station, Okitsu, Shimizu, Shizuoka Prefecture 424-02, Japan 東憉試験場興汚支場 
of distilled water: $3 \mathrm{~g}$ yeast extract, $3 \mathrm{~g}$ malt extract, $5 \mathrm{~g}$ peptone, and $10 \mathrm{~g}$ glucose $\mathrm{e}^{7}$. They were first cultured on YM agar slant at $25 \mathrm{C}$ for 4 days. Before using, the colonies were washed asepticaly two times with distilled water by centrifugation.

Physiological property . For determinations of pigmentation, Wickerham's complete (WIC) medium ${ }^{\text {) }}$ was used. WIC medium comprises trace elements such as boron, manganese and others, various vitamins, three amino acids, salts, $1 \%$ glucose as carbon source and $0.5 \%$ ammonium sulfate as nitrogen souce. Each isolate was cultured in the liquid medium on a shaker at $25 \mathrm{C}$ for 7 days. The organisms were collected and washed with distilled water by centrifugation. They were macerated in a mortar with a small amount of carborundum and extracted with $50 \mathrm{ml}$ acetone followed by $50 \mathrm{ml}$ ether. The mixture of the extracts was shaken and washed with distilled water and then taken up in ether. The extracts were assayed for optical absorption at $400-500 \mathrm{~nm}$ using a HITACHI 200 spectrophotometer.

Assimilation of nitrate was tested using a liquid and ammonium sulfate-free WIC medium with one tenth amino acid-content (WND medium). Utilization of carbohydrates and splitting of arbutin were tested using carbon source-free WIC (WCD) medium. To test vitamin requirment the vitamin-free WIC (WVD) medium was used. These media were pasteurized by filtration with a Seitz filter. Growth of the organism was determined by the turbidity of the culture at $610 \mathrm{~nm}$ wave length light 7 to 21 days after still incubation at $25 \mathrm{C}$.

Infection process . Immature leaves of potted Satsuma mandarin trees were inoculated by spraying with the cell suspension of yeast. The plants were bagged with polyethylene and held at $25 \mathrm{C}$. Four days later the bags were removed and the trees were transferred to a greenhouse controlled at $25 \mathrm{C}$.

Inoculated leaves were cut into small pieces and floated on $0.1 \%$ cotton blue solution for several minutes, keeping the undersurface in contact with the solution. The pieces were rinsed with distilled water and observed with a microscope under reflected light.

Similar leaves showing typical symptoms were collected one month after inoculation and cut into small pieces that included the lesions. The pieces were fixed with $2.5 \%$ glutaraldehyde and then $1 \%$ osumium tetraoxide. These were embedded into Spur's resin after dehydrogation. Ultrathin sections were made and observed with a HITACHI $\mathrm{H}-300$ electron microscope after double-staining with uranylacetate and lead nitrate.

\section{Results}

\section{Physiological property}

Pigmentation: Ether extracts of isolates No. 3, 4 and 6 were slightly orange-colored. The optical absorption curve had two peaks at 478 and $452 \mathrm{~nm}$ and a shoulder at $428 \mathrm{~nm}$ (Fig. 1). This indicates presence of carotenoids in the isolates.

Assimilation of potassium nitrate: All three isolates grew rapidly in a WND medium added with $0.765 \%$ potassium nitrate as well as in that with $0.5 \%$ ammonium sulfate; in contrast, few grew in a WND-solo medium (Fig. 2).

Assimilation of carbon sources: Assimilation of various carbon sources was 


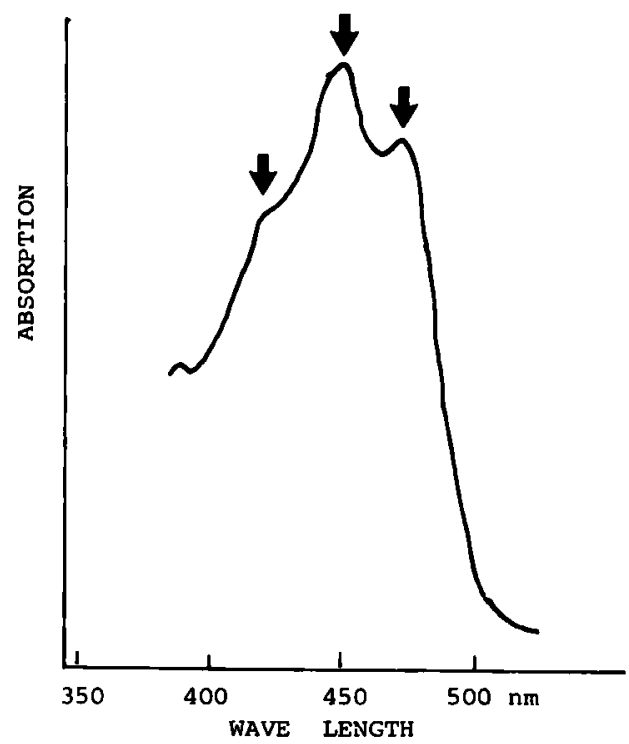

Fig. 1. Optical absorption curve of ether extract prepared from isolate No. 4 cultured on Wickerham's complete medium. Characteristic peaks indicate the presence of carotenoids.

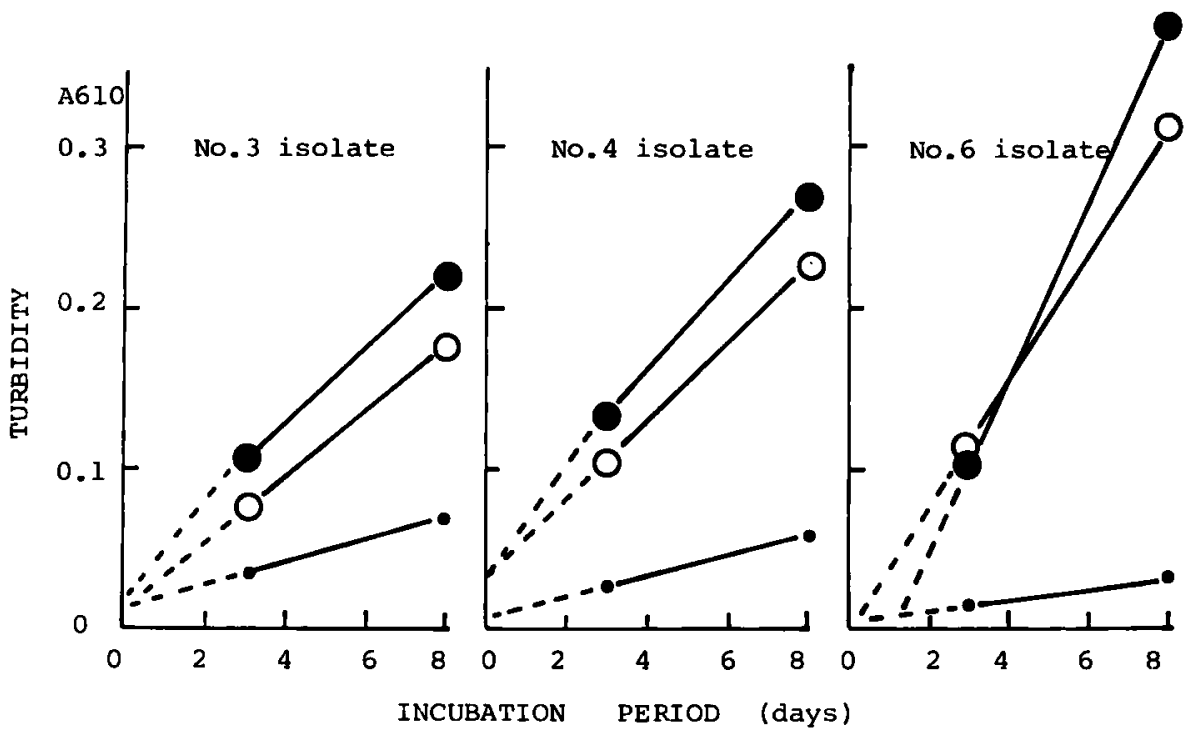

Fig. 2. Growth of three isolates of pseudo greasy spot-causal yeast in a nitrogen-source-free Wikerham's medium (WND), $\bullet$, WND plus potassium nitrate, $O$, and WND plus ammonium sulphate,

tested on a WCD agar plate (auxanograph method) and the liquid medium. Abundant growth of the yeast was observed when the following carbon sources were added to the medium: glucose, maltose, sucrose, trehalose, raffinose, D-xylose, glycerol, adonitol, Dmannitol, D-sorbitol and succinic acid. Citric acid, $\alpha$-methyl glucoside and DL-lactic 
acid promoted abundant growth on the agar plate, but little growth on the liquid medium.

Other carbon sources that provided negative growth on auxanograph were examined further in liquid culture. Inulin and salicin were rapidly assimilated by all three isolates. L-sorbose was utilized rapidly by isolates No. 3 and 4 but very weakly by No. 6 . Galactose, cellobiose, lactose, melezitose, soluble starch, both $\mathrm{D}$ - and L-arabinose and ethanol were weakly assimilated by all three isolates. Melibiose, D-ribose, L-rhamnose, i-inositol and dulcitol permitted no growth, indicating no assimilation.

Splitting of glucoside: In a WCD liquid medium added with only $1 \%$ arbutin as the carbon source, a little growth of all three isolates was observed for 6 days, but no further growth was observed. In contrast, abundant growth was observed in the complete Whickerham's medium. These facts indicate that arbutin is split into glucose and phenol by the yeasts and the glucose was assimilated by them, but that further multiplication is inhibited by the phenol.

Vitamin requirement: For first two days no growth of the yeasts was detected in a vitamin-free Wickerham (WVD) medium. However, they grew definitely when observed 5 days after incubation. In a WVD medium added with each vitamin the yeast cells also grew. Among vitamins tested pyridoxine- $\mathrm{HCl}$ enhanced the growth in earlier stages. Relative turbidities of those cultures to that of vitamin-complete culture showed 50 to $98 \%$ when observed 5 days after incubation. These indicate that vitamins are not essential for growth of the yeast.

Production of starch-like compounds : The isolates were cultured for 7 days at $25 \mathrm{C}$ in a synthetic agar medium containing $0.1 \%$ ammonium sulfate, $0.1 \%$ monobasic potassium phosphate, $0.05 \%$ magnesium sulfate and $1 \%$ glucose. When Lugol's solution was dropped on the colonies, no color change was observed. This indicates that no starch-like compounds were produced around the colonies.

Fermentation test: The isolates were tested for their ability to ferment glucose, galactose, sucrose, maltose, lactose and raffinose. A small amount of the yeast cells were added to Einhorn's tubes containing $2 \%$ solution of the test material and $0.3 \%$ yeast-extract, followed by still incubation for 20 days at $25 \mathrm{C}$, but no gas bubbles were observed.

Other properties: When the isolates were grown on a Christensen's urea agar ${ }^{6)}$ for 6 days at $25 \mathrm{C}$, the color of medium was changed to deep pink. This change indicates alkalization due to production of ammonia from urea by the yeasts.

Ability to grow on high concentration of sugar was tested on an agar media containing $50 \%(\mathrm{w} / \mathrm{w})$ glucose and $0.5 \%$ yeast extracts (w/w), but no growth was observed.

\section{Infection process}

Mode of infection: When the undersurface of inoculated leaves was observed five days after inoculation, yeast cells were scattered over the surface and some of them were attached to guard cells. By 7 days after inoculation the yeasts had multiplied abundantly and formed colonies, and some of them were located in the stomatal pores (Plate I -1). Necrotic guard cells were observed at 21 days after inoculation (Plate I -2).
Histological changes :
A preliminary study using a light microscope and Stough- 


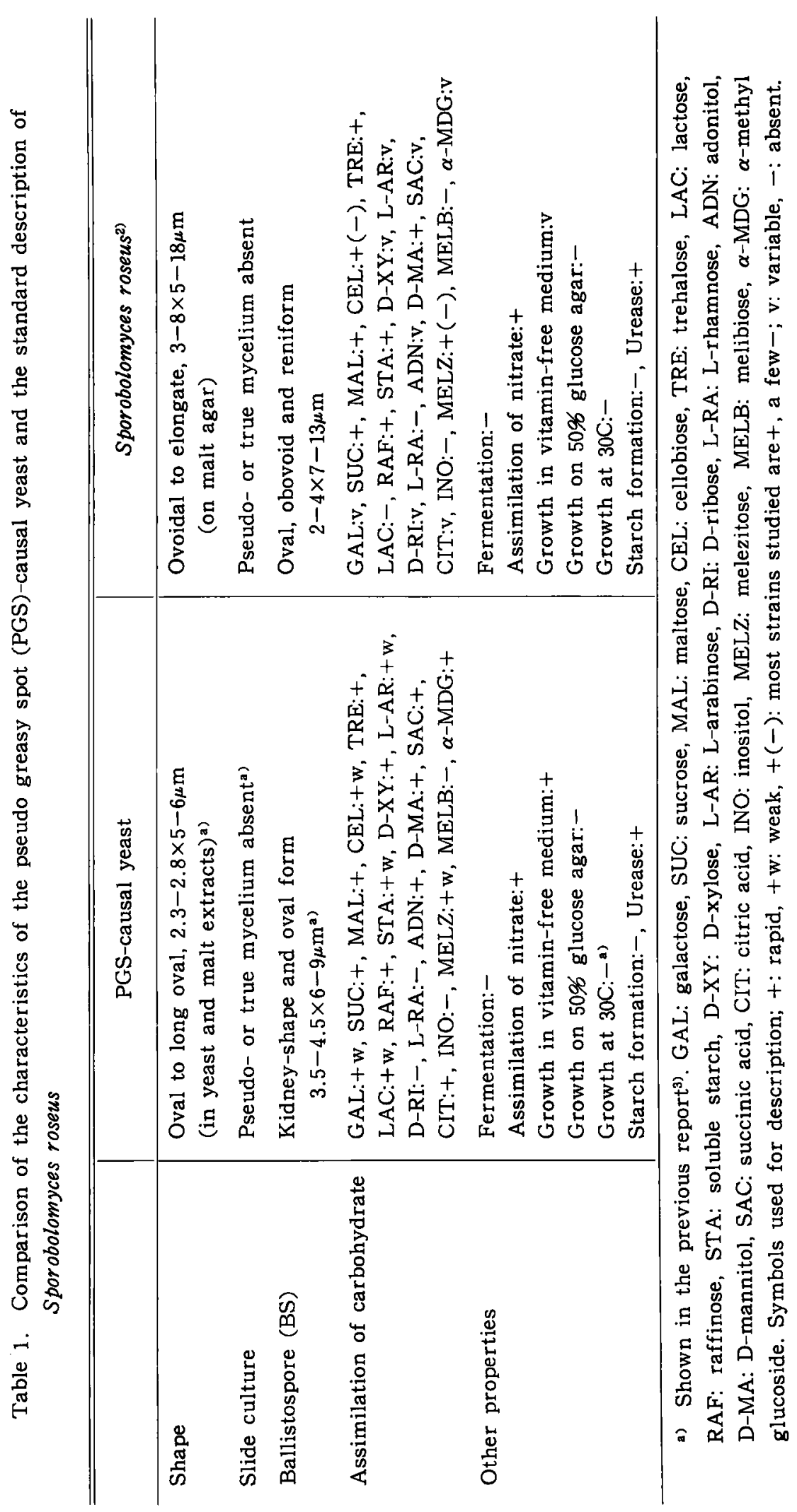


ton's stain method showed that many of the intercellular spaces of diseased tissues were plugged with gum-like materials and that adjacent parenchyma cells were slightly enlarged. However, these intercellular spaces were stained too dark to detect any yeast bodies there. Electron-microscopy revealed that many yeast cells were embedded in these intercellular spaces (Plate I-4). Some of the yeast cells were budding. Other yeast cells were electron-dense, indicating necrosis (Plate I -5). In other cases, the yeast was bound with the walls of parenchyma cells (Plate I-6). Cell wall of these embedded yeasts was rather thick, $0.5-0.8 \mu \mathrm{m}$; in contrast to that of the yeasts collected from YM liquid culture which was less than $0.1 \mu \mathrm{m}$ in thickness (Plate I -3 ).

Host cells adjacent to the yeasts were not collapsed, and they showed intact cytoplasm. However, plasmalemma and tonoplasts nearer to the yeast were partially destroyed (Plate I -6). Vacuoles were rather enlarged. Chloroplasts were degenerated based on the increase of spherical and electrondense bodies (Plate I -5).

\section{Discussion}

Ballistosporobologenus, Sporobolomycetaceae, include two genera, Sporobolomyces and Bullera. In the second edition of 'The Yeasts's' the genus Sporobolomyces was characterized by carotenoid pigmentation and kidney- or asymmetric shape ballistospores. However, the distinction is changed in the third and revised edition ${ }^{4}$ which published after the publication of previous report ${ }^{33}$, especialy in the shape of ballistospores. The ballistospores of Sporobolomyces are now described as bilaterally symmetrical, in contrast, those of Bullera as usually rotationally symmerical. The previous report showed that half of the ballistospores were kidney-shape and others were oval. Therefore, PGS-causal yeast is also belonged to the genus Sporobolomyces in the revised taxonomy system.

When the properties of PGS-causal yeast are collated with the key to the species of the genus Sporobolomyces ${ }^{2}$, those evidence of i-inositol not assimilated, nitrate assimilated, pseudo- or true mycelium not present and soluble starch assimilated lead to the identification of $S$. roseus Kluyver et van Niel. The assimilation of starch distinguishes S. roseus from S. salmonicolor (Sporiäiobolus salmonicolor in the perfect stage), which can not or can weakly assimilate it. This raises a doubt in the identification because of the weak assimilation of PGS-causal yeast. However, most isolates of S. salmonicolor are able to grow at $30 \mathrm{C}^{1)}$, in contrast, $S$. roseus ${ }^{2)}$ and PGS-causal yeast ${ }^{3)}$ are not grown at the temperature. The characteristics of the PGS-causal yeast agree with the standard description of $S$. roseus as shown in Table 1, therefore, PGS-causal yeast is identified as $S$. roseus.

The PGS-causal yeast multiplies on the surface of citrus leaves and some of the yeast cells enter the leaf through the stomatal pores and multiply in the intercellular spaces. Host plant reactions occur soon after the infection. Host cells near the yeast colonies do not collapse immediately, but some degenerations of the membrane system and chloroplasts occur in them. The affected cells increase in size and later the intercellular spaces become plugged with gum to develop a greasy spot symptom. 
The author is grateful to Dr. Jack O. Whiteside, Citrus Research and Education Center, University of Florida, for his critical reading of this manuscript.

\section{Literature cited}

1. Fell, J. W. and Statzell Tallman, A. (1984). In The Yeasts, a taxonomic study, 3rd edition. (Kreger-van Rij, N. J. W. ed.). Elsevier Science Publishers B. V., Amsterdam, pp. 532-540.

2. Fell, J. W. and Statzell Tallman, A. (1984). Ibid. pp. 911-920.

3. Koizumi, M. and Kuhara, S. (1984). Ann. Phytopath. Soc. Japan $50: 620-627$.

4. Kregaer-van Rij, N. J. W. (1984). In The Yeasts, a taxonomic study, 3rd edition. (Kreger-van Rij, N. J. W. ed.). Elsevier Science Publishers B. V., Amsterdam, pp. 35-36.

5. Phaff, H. J. (1970). In The Yeasts, 2nd edition (Lodder, J. ed.). North-Holland Publishing Co., Amsterdam, pp. 341-369.

6. Van der Walt, J. P. and Yarrow, D. (1984). In The Yeasts, a taxonomic study, 3rd edition. (Kreger-van Rij, N. J. W. ed.). Elsevier Science Publishers B. V., Amsterdam, pp. 45-104.

7. Wickerham, L. J. (1951). U. S. Dept. Agr. Tech. Bull. $1029: 1-56$.

\section{和 文 摘 要}

小家銘冊：カンキツにせ黄斑病菌 Sporobolomyces roseus の同定とその感染様式

カンキツにせ黄斑病を起こす射出胞子帅成酵母の分類学的㷌属を朋らかにした。本菌はカロチノイドを有

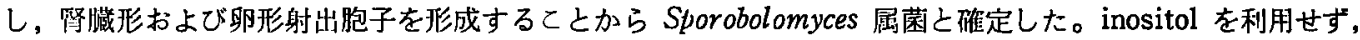

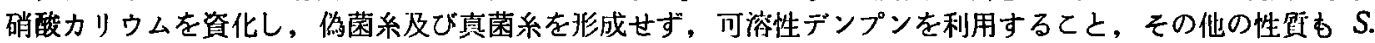
roseus の原記哉とほぼ一致するととからう. roseus Kluyver et van Niel と同定した。坊原菌はカンキツ㷊

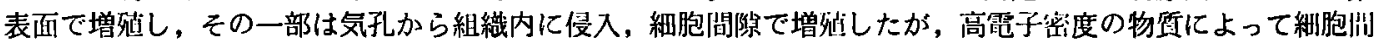

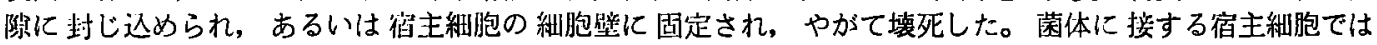
plasmalemma と tonoplast が沙壊し，葉緑体が变性，液胞は拡大したが，細胞壊死は見られなかった。

\section{Explanation of plate}

\section{Plate I}

1. Yeast cells of isolate No. 3 multiplying on the undersurface of an immature leaf of Satsuma mandarin 16 days after inoculation. Note presence of the yeast cells in a stomata.

2. A diseased guard cell on the satsuma mandarin leaf 21 days after inoculation with isolate No. 6.

3. An electronmicroscopy of cross section of isolate No. 3 collected from yeast extractmalt extract liquid culture. Note slender cell wall.

4-6. Ultrastructure of disease tissues of the satsuma mandarin leaves, 30 days after inoculation with isolate No. 6; 4, embedding of yeast cells (y) with electron-dense materials in intercellular spaces; 5 , necrotic yeast cells and degeneration of chloroplasts (c) in the parenchyma; 6, immobility adherence of yeast (y) on the surface of host cell wall (w). Note markedly thickened wall of the yeast cell ( $Y W$ ). An arrow indicates degenerated tonoplast.

Bar represents $10 \mu \mathrm{m}$ in plates 1 and 2 and $1 \mu \mathrm{m}$ in plates $3-6$. 


\section{Plate I}
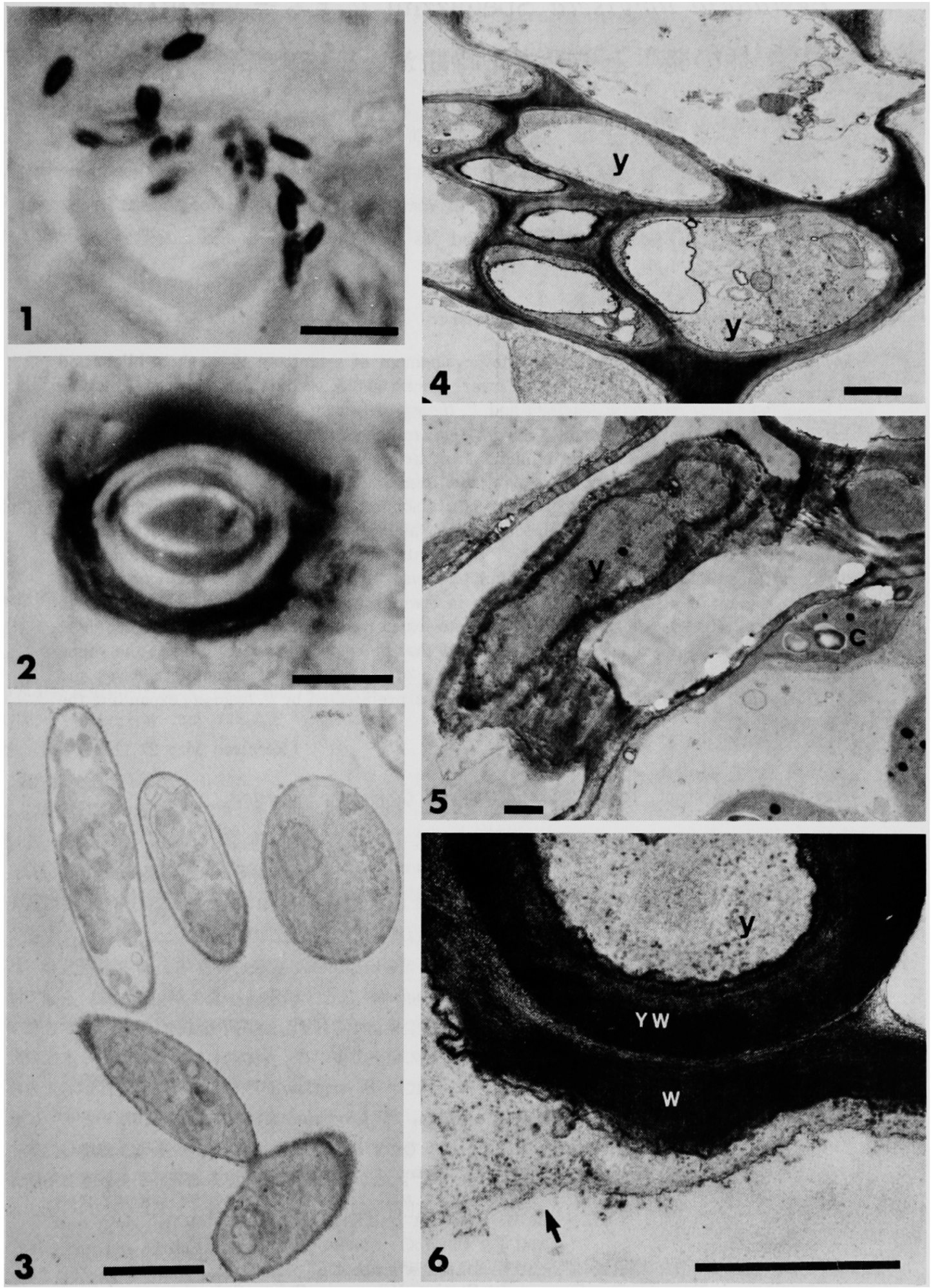